\title{
Nepojasnjeno povišanje aktivnosti aspartat aminotransferaze: prikaz primera
}

\section{Cryptogenic Increased Activity of Aspartate Aminotransferase: a Case Report}

Tjaša Žagar, Rok Orel

\section{Izvleček}

$\checkmark$ prispevku prikazujemo primer nepojasnjeno povišane aktivnosti aspartat aminotransferaze (AST). AST je encim, ki se nahaja v številnih tkivih, zato je serumska aktivnost tega encima lahko povišana pri različnih boleznih. Pri izoliranem povišanju AST smo zato postavljeni pred diagnostični izziv, ki zahteva, da izključimo številne bolezni. Če jih z veliko verjetnostjo izključimo, govorimo o nepojasnjenem povišanju aktivnosti AST. Izsledki nekaterih raziskav so pokazali, da lahko del povišanja pojasnimo z makroencimi, točneje z makro AST. Tudi v prikazanem primeru smo postavili sum, da je povišana aktivnost AST posledica makro AST. Ker v laboratoriju Univerzitetnega kliničnega centra Ljubljana določitev makro AST ni mogoča, diagnoze nismo niti potrdili niti ovrgli.

Ključne besede: aspartat aminotransferaza (AST), makroencimi, purpura, trombocitopenija. 


\section{Uvod}

Tolmačenje zvišane ravni jetrnih encimov pri brezsimptomnih otrocih je težavno. Posebej težko pojasnimo izolirano zvišanje aktivnosti aspartat aminotransferze (AST) (1). AST je encim, ki se nahaja v številnih tkivih, v klinično pomembnih količinah pa je prisoten $v$ jetrih, srcu, skeletnih mišicah ter $v$ manjši meri v eritrocitih in ledvicah (2, 3). Tako je lahko zvišana vrednost AST posledica bolezni jeter, srca, skeletnih mišic, hemolitičnih bolezni, bolezni ledvic ali celo jemanja zdravil (eritromicin) $(1,3)$. Poznamo dva izoencima AST: citosolni AST (CAST) in mitohondrijski AST (mAST). Celotno serumska aktivnost AST odraža predvsem aktivnost citosolnega izoencima, mitohondrijski izoencim pa prispeva $\mathrm{k}$ celotni serumski aktivnosti AST le pri hudih poškodbah tkiva. Zato je analiza izoencimov pomembna, saj si $z$ določitvijo mAST lahko na primer pomagamo pri oceni stopnje poškodbe jeter in srčne mišice $(4,5)$.

Od leta 1964 poznamo pojem makroencimi (6). To so kompleksi plazemskih encimov $z$ imunoglobulini ali pa nastanejo s samo polimerizacijo $(1,6)$. Zaradi velikosti se težko izločajo preko glomerulov in ostajajo v krvi, s tem pa povečajo celotno serumsko aktivnost določenega encima (1). Domnevajo, da so makroencimi specifični kompleksi protiteles $z$ antigeni (4). Makroencime najdemo v serumu pri zdravih ljudeh, pogosto pa tudi pri nekaterih imunsko pogojenih, neoplastičnih in drugih boleznih $(2,7,8)$. Patogeneza makroencimov še ni pojasnjena. Nekateri viri omenjajo možnost, da gre za genetsko nagnjenost, nenormalen odziv imunskega sistema ali motnjo imunske tolerance $(6,8)$. Poznamo različne makroencime, kot so makro amilaza, makro laktat dehidrogenaza, makro alkalna fosfataza, makro kreatin kinaza, makro lipaza, makro gama glutamil transferaza in tudi makro AST (1). Ti encimski kompleksi so biološko neaktivni (7). Makro AST je prvi opisal Konttinen s sodelavci leta $1978(1,5)$.
Za dokaz makro encimov uporabljamo različne laboratorijske metode. Pogosto za presejalno testiranje uporabljamo precipitacijo $v$ polietilen glikolu (PEG) $(3,8)$. Kot cenejšo in enostavnejšo alternativo Davidson in Watson ter Castiella s sodelavci opisujejo značilno zmanjšanje serumske aktivnosti makro AST, če serum en teden shranjujemo pri temperaturi $4{ }^{\circ} \mathrm{C}$. Kot vzrok znižanja aktivnosti AST navajajo nestabilnost kompleksa imunoglobulina in AST $(9,10)$. Standardna metoda za določanje makro AST je gelska filtracijska kromatografija (11).

Zaradi redkosti makro AST laboratorijskega določanja ne opravljamo rutinsko. Ob povišanih vrednostih encima pogosto opravljamo številne drage in za bolnika celo nevarne diagnostične preiskave (9). Različni viri predlagajo, da ob izolirani povišani aktivnosti AST poleg običajne anamneze, kliničnega statusa in osnovnih laboratorijskih preiskav bolnika natančno izprašamo o jemanju zdravil in pitju alkohola. $Z$ jetrnimi testi izključimo jetrne bolezni. $Z$ določanjem aldolaze in kreatin kinaze izključimo bolezen mišic. Hemolitično bolezen izključimo $z$ določanjem laktat dehidrogenaze. Ob negativni anamnezi in statusu ter normalnih laboratorijskih izvidih pomislimo na možnost makro AST v serumu $(1,3,7)$.

\section{Predstavitev primera}

Predstavljamo primer 7-letnega dečka, pri katerem smo v laboratorijskih izvidih več kot eno leto opažali povišano aktivnost AST v serumu.

Deček je bil približno eno leto pred pregledom v naši ambulanti sprejet v področno bolnišnico zaradi povišane telesne temperature, bolečine $v$ desnem kolenu ter generaliziranega petehialnega izpuščaja in purpure po udih in glutealno.

V sklopu diagnostičnih preiskav so opravili laboratorijske preiskave krvi in urina. V krvi so opažali zmanjšano število levkocitov $\left(3,9 \times 10^{9} / \mathrm{l}\right)$ in trombocitov $\left(114 \times 10^{9} / \mathrm{l}\right)$ ter zvišano vrednost AST $(1,44 \mu \mathrm{kat} / \mathrm{l})$. Izvid osnovnih urinskih preiskav je bil v mejah normalnih vrednosti. Med petdnevno hospitalizacijo so laboratorijske preiskave ponavljali, rezultati pa so bili podobni (Tabela 1). Test določanja krvi v blatu je bil negativen. Opravili so tudi rentgensko slikanje (RTG) prsnega koša, ki je bil v mejah normale. Zaradi povišane telesne temperature so opravili bris nazofarinksa na virus influence $A$ in virus influence $B$, ki je bil negativen. Na dan odpusta je bilo število levkocitov in trombocitov še vedno zmanjšano, vrednost AST pa še vedno zvišana (Tabela 1).

Zaključili so, da je znižano število levkocitov in trombocitov najverjetneje posledica prebolevanja viroze. Zaradi petehialnega izpuščaja in purpure so postavili sum na Henoch-Schönleinovo purpuro (HSP).

Zaradi povišane vrednosti AST so svetovali redne kontrole jetrnih testov, zaradi suma na HSP pa spremljanje osnovnih urinskih parametrov (predvsem z namenom izključevanja mikrohematurije in proteinurije) in krvnega tlaka enkrat mesečno.

Ob kontrolnih pregledih pri osebnem pediatru je bil krvni tlak primeren, število levkocitov in trombocitov pa znotraj referenčnih vrednosti. Le ko je fant ponovno preboleval okužbo, je bilo število levkocitov in trombocitov zmanjšano. Vrednost AST je bila povišana ob vsakem kontrolnem pregledu (Tabela 1).

Ker je povišana aktivnost AST vztrajala več kot eno leto, je dečka osebna pediatrinja napotila $v$ gastroenterološko ambulanto. Pred pregledom pri nas je deček že imel opravljen ultrazvok (UZ) trebuha, ki ni pokazal pomembnejših odstopanj od normalnih vrednosti. Ob pregledu v naši ambulanti je bil deček dobrega počutja, v kliničnem statusu pa ni bilo odstopanj. Pregledali smo dokumentacijo, ki so jo prinesli s seboj. Iz vsega zapisanega ter že opravljenih 


\begin{tabular}{|c|c|c|c|c|c|c|c|c|c|c|c|}
\hline Preiskave & & $\begin{array}{r}\text { AST } \\
\mu k a t / /\end{array}$ & $\begin{array}{r}\text { ALT } \\
\mu k a t / /\end{array}$ & $\begin{array}{r}\text { GGT } \\
\mu \mathrm{kat} / \mathrm{I}\end{array}$ & $\begin{array}{r}\text { CK } \\
\mu k a t / I\end{array}$ & $\begin{array}{r}\text { LDH } \\
\mu \mathrm{kat} / \mathrm{I}\end{array}$ & $\begin{array}{r}\text { trombociti } \\
\times 10^{9} / 1\end{array}$ & $\begin{array}{r}\text { levkociti } \\
\times 10^{9} / 1\end{array}$ & $\begin{array}{r}\text { eritrociti } \\
\times 10^{12} / 1\end{array}$ & pč-INR & $\begin{array}{r}\text { aldolaza } \\
\text { nkat/l }\end{array}$ \\
\hline & $\begin{array}{l}\text { referenčne } \\
\text { vrednosti } \\
\text { za starost } \\
7 \text { let (12) }\end{array}$ & $<0,69$ & $<0,43$ & $0,06-0,37$ & $<2,50$ & $<5,62$ & $150-350$ & $4,5-14,5$ & $4,0-5,2$ & $0,87-1,20$ & $<250$ \\
\hline \multirow{3}{*}{$\begin{array}{l}\text { v področni } \\
\text { bolnišnici }\end{array}$} & 04.02 .19 & 1,44 & 0,21 & 0,15 & & & 114 & 3,9 & 4,79 & 1,02 & \\
\hline & 07.02 .19 & 1,16 & 0,18 & 0,15 & 0,63 & 3,94 & 92 & 3,4 & 4,69 & & \\
\hline & 09.02 .19 & 1,26 & & & & 3,63 & 110 & 3,3 & 4,96 & & \\
\hline \multirow{4}{*}{$\begin{array}{l}\text { ob kontrolah } \\
\text { pri osebnem } \\
\text { pediatru }\end{array}$} & 15.02 .19 & 1,49 & 0,31 & 0,15 & & & 247 & 6,0 & & & \\
\hline & 13.09 .19 & 1,47 & 0,22 & & & & 259 & 6,9 & & & \\
\hline & 07.02 .20 & 1,66 & 0,24 & 0,23 & & & 126 & 2,3 & & & \\
\hline & 13.02 .20 & & & & & & 302 & 6,2 & & & \\
\hline $\begin{array}{l}\text { v gastroentero- } \\
\text { loški ambulanti }\end{array}$ & 03.03 .20 & 1,34 & 0,25 & 0,17 & 1,91 & 4,19 & & & & & 88 \\
\hline
\end{tabular}

TABELA 1. LABORATORIJSKE VREDNOSTI PRI BOLNIKU.

TABLE 1. PATIENT'S LABORATORY VALUES.

preiskav smo posumili, da bi lahko šlo za benigno povišanje AST. Odločili smo se za ponovno kontrolo jetrnih encimov. Za izključitev bolezni skeletnih mišic in hemolitične bolezni, ob katerih je prav tako možno povišanje AST, smo kontrolirali vrednosti LDH, CK in aldolaze (Tabela 1). Vse vrednosti, razen AST, so bile znotraj referenčnih. Tako smo zaključili, da gre najverjetneje za benigno povišanje AST, verjetno makro AST. V laboratoriju Univerzitetnega kliničnega centra $v$ Ljubljani smo se pozanimali, ali obstaja možnost laboratorijskega diagnosticiranja, a so nam povedali, da testa rutinsko ne izvajajo. Zato smo svetovali redne kontrole kliničnega statusa in jetrnih testov pri osebnem zdravniku.

\section{Razpravljanje}

Prikazali smo primer 7-letnega dečka, pri katerem so ob hospitalizaciji v področni bolnišnici zaradi suma na HSP prvič ugotavljali povišane vrednosti AST. Ker laboratorijske analize jetrnih testov niso bile opravljene, ne vemo, ali se je povišanje AST pojavilo ob prebolevanju HSP oziroma okužbe, ali je bila vrednost tega encima morda povišana že prej in so jo ob razširjenih laboratorijskih preiskavah med hospitalizacijo le naključno odkrili.

HSP je najbolj pogost vaskulitis otroške dobe, za katerega je značilna tetrada znakov in simptomov: purpura, artritis ali artralgija, bolečina v trebuhu in ledvične bolezni. Za postavitev diagnoze HSP je nujno dokazati prisotnost petehij ali purpur brez trombocitopenije in še vsaj enega od simptomov ali znakov: (i) artritis ali artralgija, (ii) prizadetost ledvic, (iii) bolečina v trebuhu in (iv) levkocitoklastični vaskulitis ali proliferativni glumerulonefritis $s$ prevladujočimi IgA-depoziti na patohistološkem preparatu $(13,14)$.

Pri dečku sta bili prisotni purpura in artralgija, zato so v področni bolnišnici postavili sum na HSP. V laboratorijskih izvidih so ugotavljali tudi blago trombocitopenijo, ki so jo pojasnili v sklopu prebolevanja okužbe. Trombocitopeni- ja je pogosta pri prebolevanju virusnih okužb $(15,16)$. Ob prebolevanju okužbe čez približno eno leto je imel deček ponovno znižane vrednosti levkocitov in trombocitov, petehialni izpuščaj pa se ni pojavil.

V opisanem primeru nismo opredelili jasnega vzroka povišane aktivnosti AST v serumu. AST je namreč prisotna $v$ številnih tkivih in je tako lahko povišana pri različnih boleznih (npr. pri boleznih jeter, srca in skeletnih mišic, hemolitičnih boleznih, boleznih ledvic), prav tako je lahko povišana ob jemanju zdravila eritromicin $(1,3)$. Z natančno anamnezo ter laboratorijskimi in drugimi preiskavami (UZ trebuha, RTG prsnega koša) smo navedena stanja z veliko verjetnostjo izključili. Postavili smo sum, da je pri dečku serumska aktivnost AST povišana zaradi makro AST. Ker rutinsko določanje makro AST pri nas ni mogoče, suma nismo mogli niti potrditi niti ovreči ${ }^{1}$. Tako je

1 Lahko bi opravili presejalni test, ki ga opisujejo Davidson in Watson ter Castiella s sodelavci $(9,10)$ a zaradi epidemije covid-19 dečka nismo klicali na ponovni odvzem krvi. 
mogoče, da je v ozadju nek drug vzrok povišanja aktivnosti AST. $V$ raziskavi na vzorcu 44 otrok z nepojasnjeno povišano aktivnostjo AST so le pri 17 potrdili, da gre za makro AST, pri ostalih pa povišane aktivnosti AST niso uspeli pojasniti (8). Obstaja tudi manjša verjetnost, da bi bile vrednosti AST za dečka normalne. Referenčni intervali laboratorijskih preiskav imajo večinoma 95-odstotni interval zaupanja, kar pomeni, da ima 2,5\% zdrave populacije nižje, 2,5 \% pa višje vrednosti od mej referenčnega intervala (17).

\section{Zaključek}

S prikazanim primerom smo želeli opozoriti na možnost benignega povišanja aktivnosti AST. Trenutno lahko postavimo sum na makro AST, in sicer po izključitvi vseh nevarnejših vzrokov povišane aktivnosti transaminaze. Ker diagnoze ne moremo potrditi, svetujemo redno spremljanje klinične slike in laboratorijskih izvidov.

\section{Literatura}

1. Rohani P, Imanzadeh F, Sayyari A, Kazemi Aghdam M, Shiari R. Persistent elevation of aspartet aminotransferase in a child after incomplete Kawasaki disease: a case report and literature review. BMC Pediatr 2020; 20(1): 73.

2. Sass A D, Chadalavada R. Clinical communication to the editor: Unexplained isolated elevation in serum aspatrat aminotransferase: think macro! Am J Med 2007; 120(9): e5-6.

3. Lord R, Fahie-Wilson M, Suri S. A pediatric case of macro aspartate aminotransferase: Case report. Ann Clin Biochem 2008; 45: 323-4.

4. Moriyama T, Tamura S, Nakano K, Otsuka K Shigemura M, Honma N. Laboratory and clinical features of abnormal macroenzymes found in human sera. Biochim Biophys Acta 2015; 1854(6): 658-67.

5. Konttinen A, Murros J, Ojala K, Salaspuro M, Somer H, Rasanen J. A new cause of increased serum aspartate aminotransferase activity. Clinica Chemica Acta 1978; 84: 145-7.

6. Chtioui H, Mauerhofer O, Günther B, Dufour JF. Macro-AST in an asymptomatic yung patient. Ann Hepatol 2010; 9(1): 93-5.

7. Mbagaya W, Foo J, Luvai A, King C, Mapplebeck S, Gough A, Jassam N. Persistently raised aspartate aminotransferase (AST) due to macro -AST in rheumatology clinic. Diagnosis 2015; 2(2): $137-40$.
8. Caropreso M, Fortunato G, Lenta S, Palmieri D, Esposito M, Vitale DF et al. Prevalence and long-term course of macro-aspartate aminotransferase in children. J Pediatr 2009; 154(5): 744-8.

9. Davidson DF, Watson DJ. Macroenzyme detection by polyethylene glycol precipitation. Ann Clin Biochem 2003; 40: 514-20.

10. Castiella A, Aguayo FJ, Rueda M, Fernandez J, Zapata E. Macro-aspartate aminotransferase (Macro-AST) a rare cause of hyper-transaminasemia: Another way to diagnosis? J Clin Gastroenterol 2006; 40: 655.

11. Raya GA, Zúñiga RC, Salido EM. Isolated elevation of aspartat aminotransferase (AST) in an asymptomatic patient due to macro-AST. J Clin Lab Anal 2019; 33(2): e22690.

12. Vincek K, Mramor M. Bolj ali manj nujna stanja v pediatriji. Ljubljana: Društvo za pomoč otrokom s presnovnimi motnjami; 2017.

13. Trnka P. Henoch-Schönlein purpura in children. J Paediatr Child Health 2013; 49(12): 995-1003.

14. Hetland LE, Susrud KS, Lindahl KH, Bygum A. Henoch-Schönlein purpura: a literature review. Acta Derm Venereol 2017; 97: 1160-6.

15. Assinger A. Review Article: Platelets and infection - an emerging role of platelets in viral infection. Front Immunol 2014; 5: 649.

16. Franchini M, Veneri D, Lippi G. Thrombocytopenia and infections. Expert Rev Hematol 2014; 123(18): 2759-67.

17. Katayev A, Balciza C, Seccombe DW. Establishing reference intervals for clinical laboratory test results: is there a better way? Am J Clin Pathol 2010; 133(2): 180-6.

Tjaša Žagar, dr. med. (kontaktna oseba/contact person) Klinični oddelek za gastroenterologijo, hepatologijo in nutricionistiko, Pediatrična klinika, Univerzitetni klinični center Ljubljana

Bohoričeva 20, 1000 Ljubljana, Slovenija e-naslov: tjasa.zagar0@gmail.com

prof. dr. Rok Orel, dr. med.

Klinični oddelek za gastroenterologijo, hepatologijo in nutricionistiko Pediatrična klinika, Univerzitetni klinični center Ljubljana, Ljubljana, Slovenija in Katedra za pediatrijo, Medicinska fakulteta Ljubljana, Ljubljana, Slovenija

prispelo / received: 24. 9. 2020 sprejeto / accepted: 7. 12. 2020

Žagar T, Orel R. Nepojasnjeno povišanje aktivnosti aspartat aminotransferaze: prikaz primera. Slov Pediatr 2021; 28(1): 43-46. https://doi. org/10.38031/slovpediatr-2021-1-07. 